\title{
Short-term feed intake is regulated by macronutrient oxidation in lactating Holstein cows
}

\author{
M. Derno, ${ }^{*}$ G. Nürnberg,† P. Schön, $\ddagger$ A. Schwarm, ${ }^{*}$ M. Röntgen, ${ }^{*}$ H. M. Hammon, ${ }^{\star}$ C. C. Metges, ${ }^{*}$ \\ R. M. Bruckmaier, $\S$ and B. Kuhla*1 \\ *Research Unit Nutritional Physiology "Oskar Kellner," \\ †Research Unit Genetics and Biometry, and \\ $\ddagger$ Research Unit Behavioral Physiology, Leibniz Institute for Farm Animal Biology (FBN), Wilhelm-Stahl-Allee 2, 18196 Dummerstorf, Germany \\ §Veterinary Physiology, Vetsuisse Faculty, University of Bern, Bremgartenstrasse 109a, 3001 Bern, Switzerland
}

\section{ABSTRACT}

In addition to plasma metabolites and hormones participating as humoral signals in the control of feed intake, oxidative metabolic processes in peripheral organs also generate signals to terminate feeding. Although the degree of oxidation over longer periods is relatively constant, recent work suggests that the periprandial pattern of fuel oxidation is involved in regulating feeding behavior in the bovine. However, the association between periprandial oxidative metabolism and feed intake of dairy cows has not yet been studied. Therefore, the aim of this study was to elucidate possible associations existing between single feed intake events and whole-body net fat and net carbohydrate oxidation as well as their relation to plasma metabolite concentrations. To this end, 4 late-lactating cows equipped with jugular catheters were kept in respiratory chambers with continuous and simultaneous recording of gas exchange and feed intake. Animals were fed ad libitum (AL) for $24 \mathrm{~h}$ and then feed restricted (RE) to $50 \%$ of the previous AL intake for a further $24 \mathrm{~h}$. Blood samples were collected hourly to analyze $\beta$-hydroxybutyrate (BHBA), glucose, nonesterified fatty acids (NEFA), insulin, and acylated ghrelin concentrations. Crosscorrelation analysis revealed an offset ranging between 30 and 42 min between the maximum of a feed intake event and the lowest level of postprandial net fat oxidation $\left(\mathrm{FOX}_{\text {net }}\right)$ and the maximum level of postprandial net carbohydrate oxidation $\left(\mathrm{COX}_{\text {net }}\right)$, respectively. During the AL period, $\mathrm{FOX}_{\text {net }}$ did not increase above $-0.2 \mathrm{~g} / \mathrm{min}$, whereas $\mathrm{COX}_{\text {net }}$ did not decrease below 6 $\mathrm{g} / \mathrm{min}$ before the start of the next feed intake event. A strong inverse cross-correlation was obtained between $\mathrm{COX}_{\text {net }}$ and plasma glucose concentration. Direct cross-correlations were observed between COXnet and insulin, between heat production and BHBA, between

Received May 14, 2012.

Accepted October 22, 2012.

${ }^{1}$ Corresponding author: b.kuhla@fbn-dummerstorf.de insulin and glucose, and between BHBA and ghrelin. We found no cross-correlation between $\mathrm{FOX}_{\text {net }}$ and NEFA. During RE, FOX ${ }_{\text {net }}$ increased with an exponential slope, exceeded the threshold of $-0.2 \mathrm{~g} / \mathrm{min}$ as indicated by increasing plasma NEFA concentrations, and approached a maximum rate of $0.1 \mathrm{~g} / \mathrm{min}$, whereas $\mathrm{COX}_{\text {net }}$ decayed in an exponential manner, approaching a minimal $\mathrm{COX}_{\text {net }}$ rate of about $2.5 \mathrm{~g} / \mathrm{min}$ in all cows. Our novel findings suggest that, in late-lactating cows, postprandial increases in metabolic oxidative processes seem to signal suppression of feed intake, whereas preprandially an accelerated $\mathrm{FOX}_{\text {net }}$ rate and a decelerated $\mathrm{COX}_{\text {net }}$ rate initiate feed intake.

Key words: energy expenditure, ghrelin, insulin, feed intake control

\section{INTRODUCTION}

The control of feed intake is a complex process that results from the integration of multiple short- and longterm signals at the feed intake regulatory centers in the brain. For example, postprandial plasma metabolite and hormone concentrations occurring in response to the latest feed intake are thought to provide feedback signals that are detected, integrated, and translated into anorexic responses by neurons of the hypothalamus to terminate feed intake and delay hunger (Sartin et al., 2011). In this regard, the relations between feed intake and periprandial plasma insulin and ghrelin, and also nutrient signals such as glucose, NEFA, or BHBA, have been intensively studied in cows (Bines et al., 1983; Bradford et al., 2008; Bradford and Allen, 2008; Wylie et al., 2008). However, the association between these humoral signals and feed intake seems to depend on the physiological state of the animal and on other prerequisites that have not yet been fully resolved.

In addition to these humoral signals, metabolic oxidation in peripheral organs, specifically fatty acid oxidation in the liver, intestine, and muscle (Scharrer and Langhans, 1986; Friedman et al., 1999; Langhans et al., 2011) and carbohydrate oxidation, primarily he- 
patic and muscular glycolysis (Friedman and Tordoff, 1986), signal through the autonomous nervous system to the brain for terminating feed intake. In contrast, inhibition of peripheral fatty acid and carbohydrate oxidation increases feed intake (Friedman et al., 1999; Del Prete et al., 2004).

Knowledge about the involvement of substrate oxidation in feed intake inhibitory signaling was primarily obtained from studies with rodents and sheep. Similar signaling pathways have been proposed to exist in dairy cows, as outlined in the hepatic oxidation theory (Allen et al., 2009). For example, feeding a diet supplemented with rumen-protected fat or carnitine to cows increased fatty acid oxidation and decreased feed intake (Carlson et al., 2007; Duske et al., 2009). The greater hypophagic effect caused by unsaturated compared with saturated C18 fatty acids (Drackley et al., 1992) and by mediumchain fatty acids compared with long-chain fatty acids (Dohme et al., 2004) is presumably because the former are more rapidly oxidized. These studies support a link between fatty acid oxidation and longer-term feed intake suppression but the association between periprandial oxidative metabolism and feed intake has not yet been investigated in cows.

Our hypothesis was that short-term feed intake is linked to fuel oxidation and that whole-body net fat oxidation $\left(\mathbf{F O X}_{\text {net }}\right)$ is inversely associated with the amount of feed ingested. Therefore, the objective of the present study was to examine the interrelation between single feed intake events and periprandial $\mathrm{FOX}_{\text {net }}$ and whole-body net carbohydrate oxidation $\left(\mathbf{C O X}_{\text {net }}\right)$, in parallel with plasma metabolites and hormones linked to net fat and net carbohydrate metabolism. In this first approach, we used pregnant cows in late lactation, because in early lactation feed intake is generally decoupled from energy requirements for milk production (Drackley, 1999).

\section{MATERIALS AND METHODS}

\section{Animals, Measurement of Zootechnical Data, and Feeding}

The experiment was performed with 4 German Holstein dairy cows from the herd of the Leibniz Institute for Farm Animal Biology (FBN, Dummerstorf, Germany). Cows were in second lactation and comparable in age, DIM, BW, BCS, back fat thickness, and milk yield (Table 1). Back fat thickness was determined according to Schröder and Staufenbiel (2006) once weekly by ultrasound (Aloka SSK-500, PPG Hellige GmbH, Freiburg, Germany) 1 mo before the experiment started. Before and during the experiment, animals were milked twice daily and fed a TMR that consisted of $70 \%$ corn silage, $4 \%$ grass hay, $26 \%$ concentrate $(33 \%$ extracted soy meal, $20 \%$ corn, $17 \%$ wheat gluten, $13 \%$ wheat, $8 \%$ extracted rapeseed meal, $5 \%$ sugar beet pulp, $2 \%$ sodium hydrogen carbonate, $1.3 \%$ calcium carbonate, $0.2 \%$ sodium chloride, $8.0 \mathrm{MJ}$ of $\mathrm{NE}_{\mathrm{L}} / \mathrm{kg}$ of $\mathrm{DM}, 204 \mathrm{~g}$ of utilizable protein $/ \mathrm{kg}$ of $\mathrm{DM}$, and a mineral mixture). The composition of the TMR was as follows: $\mathrm{DM}=$ $28 \% ; \mathrm{CP}=13.6 \%$; crude fiber $=16.5 \% ; \mathrm{ME}=10.6$ $\mathrm{MJ} / \mathrm{kg}$.

\section{Animal Experiment}

The experimental procedures were in accordance with the German animal protection law and were approved by the relevant authorities of the State Government in Mecklenburg-West Pommerania. Before the experiment, animals were halter-trained and well adapted to the respiration chambers. Sixteen hours before the experiment started, cows were transferred to open-circuit respiration chambers at an ambient temperature of $15^{\circ} \mathrm{C}, 60 \%$ relative humidity, and light cycle ranging from 0600 to $1900 \mathrm{~h}$, as described previously (Derno et al., 2009). Cows had free access to water and were milked at 0630 and $1430 \mathrm{~h}$. The experiment started on the next day at $0630 \mathrm{~h}$ with continuous recording of gas exchange throughout the whole experimental period (see below) in intervals of $6 \mathrm{~min}$. On the first day of the respiration measurements, cows were fed ad libitum (AL), whereas on the second day they received $50 \%$ of the feed amount ingested during AL (restricted, RE) in meals of equal size at 0700 and $1500 \mathrm{~h}$. Starting at $0630 \mathrm{~h}$, blood samples were collected approximately every 60 min (actual collection ranged between 54 and $66 \mathrm{~min}$ ) via a jugular vein catheter connected to the outside of the chamber via tubing $(1 \mathrm{~mm}$ i.d., length $4 \mathrm{~m}$ ) using vacutainers (Vacuette, Greiner Bio-One, Kremsmunster, Austria) containing EDTA and the protease inhibitor Trasylol (Bayer, Leverkusen, Germany). Feed intake was determined every 6 min by feed disappearance as measured by using a scale connected to an electronic registration device.

\section{Indirect Calorimetry}

Body mass was measured directly before and after the transfer of the animals to the respiration chambers. Milk yield was recorded and milk samples were taken twice daily for analysis. Concentrations of $\mathrm{CO}_{2}$ and $\mathrm{CH}_{4}$ in the chamber were analyzed by infrared absorption (UNOR 610, Maihak, Hamburg, Germany), and the concentration of $\mathrm{O}_{2}$ was analyzed paramagnetically (OXYGOR 610, Maihak). Because total $\mathrm{CO}_{2}$ production $\left(\mathbf{V C O}_{2}\right)$ measured is the sum of fermentative and 
Table 1. Zootechnical parameters, feed intake, water intake, heat production, and milk yield in 4 lactating Holstein cows ${ }^{1}$

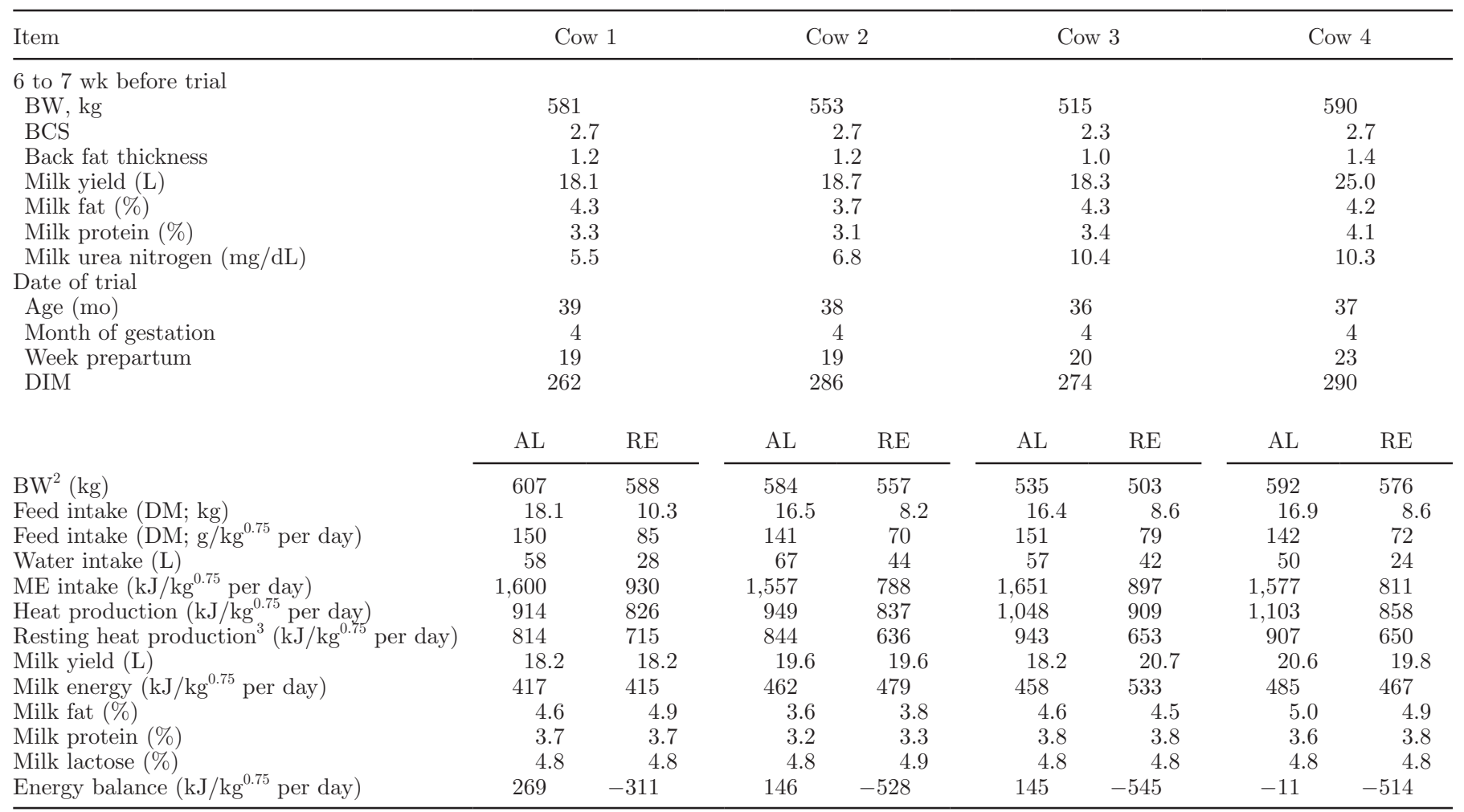

${ }^{1}$ Data are derived from a 48-h measuring period in the respiration chambers including ad libitum (AL) feeding on the first day and feed restriction (RE; $50 \%$ of the ad libitum uptake) on the second day.

${ }^{2} \mathrm{BW}$ was measured at the beginning of the AL period and at the end of RE period. Metabolic BW $\left(\mathrm{kg}^{0.75}\right)$ was calculated from the average BW. ${ }^{3}$ Mean of the 10 lowest heat production values in the nocturnal period (1900 to $0600 \mathrm{~h}$; Derno et al., 2005).

metabolic $\mathrm{CO}_{2}$, fermentative $\mathrm{CO}_{2}(\mathrm{~L})$ was estimated according to Chwalibog et al. (1996):

$$
\mathrm{CO}_{2 \text { ferm }}=1.7 \times \mathrm{CH}_{4}(\mathrm{~L}),
$$

in which the factor 1.7 remains constant for a variety of diet compositions (Blümmel et al., 1999). Metabolic $\mathrm{CO}_{2}\left(\mathrm{CO}_{2}\right.$ (metab) $)$ was calculated by subtracting $\mathrm{CO}_{2}$ (ferm) from $\mathrm{VCO}_{2}$.

Total oxygen consumption $\left(\mathbf{V O}_{2}\right)$ and $\mathrm{CO}_{2}$ (metab) were used to calculate the net disappearance rate of substrates (carbohydrates or lipids) from their respective metabolic pools, according to Simonson and DeFronzo (1990). In ruminants, carbohydrate substrates are converted in the rumen to intermediates such as VFA, lactate, or hydroxybutyrate, but gas exchange measurements consider only the total net loss of carbohydrates by oxidation $\left(\mathrm{COX}_{\text {net }}\right)$ to $\mathrm{CO}_{2}$ and $\mathrm{H}_{2} \mathrm{O}$, regardless of any formation of intermediates, exchanges, or cycling in metabolic pathways (Ferrannini, 1992). Analogously, if simultaneous oxidation and de novo synthesis of lipids occur, calorimetry yields an estimate of net fat oxidation $\left(\mathrm{FOX}_{\text {net }}\right)$, which is the algebraic sum of true lipid oxidation and lipid synthesis (Ferrannini, 1992) with- out considering intermediates such as acetate or ketone bodies, for example.

Accordingly, $\mathrm{COX}_{\text {net }}$ and $\mathrm{FOX}_{\text {net }}$ were calculated as follows:

$$
\begin{gathered}
\mathrm{COX}_{\text {net }}(\mathrm{g})=4.75 \mathrm{CO}_{2(\mathrm{metab})}(\mathrm{L}) \\
-3.23 \mathrm{O}_{2}(\mathrm{~L})-2.60 \mathrm{~N}_{\mathrm{u}}(\mathrm{g}) \\
\mathrm{FOX}_{\text {net }}(\mathrm{g})=1.69 \mathrm{O}_{2}(\mathrm{~L}) \\
-1.69 \mathrm{CO}_{2(\text { metab })}(\mathrm{L})-2.03 \mathrm{~N}_{\mathrm{u}}(\mathrm{g})
\end{gathered}
$$

As we did not measure $\mathrm{N}$ excretion in urine the term $\mathrm{N}_{\mathrm{u}}$ ( $\mathrm{N}$ excretion in urine) was set to zero, thus accepting an error of about 10\% (Simonson and DeFronzo, 1990) in the absolute values of $\mathrm{COX}_{\text {net }}$ and $\mathrm{FOX}_{\text {net }}$, respectively.

Based on the measurements of $\mathrm{O}_{2}$ consumption and $\mathrm{CO}_{2}$ and $\mathrm{CH}_{4}$ production, daily heat production $(\mathbf{H P})$ was calculated according to Brouwer (1965):

$$
\begin{gathered}
\mathrm{HP}(\mathrm{kJ})=16.18 \mathrm{O}_{2}(\mathrm{~L})+5.02 \mathrm{CO}_{2}(\mathrm{~L}) \\
-2.17 \mathrm{CH}_{4}(\mathrm{~L})-5.99 \mathrm{~N}(\mathrm{~g}) .
\end{gathered}
$$


The mean of the 10 lowest HP values determined during the nocturnal period (1900 to $0600 \mathrm{~h}$ ) was computed, reflecting energy metabolism due to resting HP and not due to digestion (Derno et al., 2005). Energy balance $\left(\mathrm{MJ} / \mathrm{kg}^{0.75}\right)$ was calculated by subtracting measured HP and calculated milk energy content from ME intake, and ME was calculated according to the recommendations of the German Society of Nutrition Physiology (GfE, 2004):

$$
\begin{aligned}
& \mathrm{ME}(\mathrm{MJ} / \mathrm{kg} \text { of DM })=6.0756+0.19123 \mathrm{EE}(\mathrm{g} / \mathrm{kg}) \\
& \quad+0.02459 \mathrm{CP}(\mathrm{g} / \mathrm{kg})-0.000038 \mathrm{CF}^{2}\left(\mathrm{~g}^{2} / \mathrm{kg}^{2}\right) \\
& -0.002139 \mathrm{EE}^{2}\left(\mathrm{~g}^{2} / \mathrm{kg}^{2}\right)-0.00006 \mathrm{CP}^{2}\left(\mathrm{~g}^{2} / \mathrm{kg}^{2}\right),[5]
\end{aligned}
$$

where $\mathrm{CF}$ is crude fiber and $\mathrm{EE}$ is crude fat from ether extract.

\section{Milk and Plasma Analyses}

Milk fat, lactose, and protein were measured at the Landeskontrollverband für Leistungs- und Qualitätsprüfung Mecklenburg-Vorpommern e.V. (Güstrow, Germany) by infrared absorption (Foss MilkoScan, Hillerød, Denmark). Energy-corrected milk was calculated as follows: $\mathrm{ECM}(\mathrm{kg})=(0.038 \times \mathrm{g}$ of crude fat +0.024 $\times \mathrm{g}$ of $\mathrm{CP}+0.017 \times \mathrm{g}$ of lactose $) \times \mathrm{kg}$ of milk $/ 3.17$ (Reist et al., 2002).

Blood was centrifuged immediately after withdrawal at $1,570 \times g$ for $20 \mathrm{~min}$ at $4^{\circ} \mathrm{C}$ to obtain plasma. An aliquot of $1 \mathrm{~mL}$ of plasma was treated with $50 \mu \mathrm{L}$ of $1 \mathrm{~N}$ $\mathrm{HCl}$ and stored at $-80^{\circ} \mathrm{C}$ for ghrelin analysis. Ghrelin was measured using an RIA kit (\#GHRA-88HK; Linco Research, St. Charles, MO) specific for the octanoyl moiety at $\mathrm{Ser}^{3}$ (active ghrelin; Wertz et al., 2003). Concentrations of plasma BHBA, cholesterol, glucose, NEFA, and urea were determined by routine analyses (Cobas Mira, Clinic for Cattle, Stiftung Tierärztliche Hochschule Hannover, Hannover, Germany) using the following commercial kits: BHBA (no. RB 1008) from Randox Laboratories Ltd. (Crumlin, UK); cholesterol (no. 553-124) from MTI Diagnostics (Idstein, Germany); glucose (GOD-PAP, LT-GL 0103) from Labor+Technik Lehmann (Berlin, Germany); NEFA (no. 434-91795) from Wako Chemicals (Neuss, Germany); and urea (no. LT-UR 0050) from Labor+Technik Lehmann. Plasma immunoreactive insulin was determined by RIA as previously described (Vicari et al., 2008)

\section{Data Analysis and Statistics}

For the description of a dependency between 2 time series (e.g., feed intake and $\mathrm{FOX}_{\text {net }}$ ), time series analy- ses were performed for each individual animal. To this end, cross-correlation functions were estimated using Proc Timeseries of SAS (version 9.2; SAS Institute Inc., 2009). The sample cross-correlation function is an estimate of the correlation between 2 time series at lags $k$ $=0, \pm 1, \pm 2, \pm 3, \ldots$. The lags used for the calculation of cross-correlation functions were equidistant $6 \mathrm{~min}$ for feed intake, $\mathrm{COX}_{\text {net }}$, and $\mathrm{FOX}_{\text {net }}$, whereas lags for plasma variables ranged between 54 and $66 \mathrm{~min}$. The maximum or minimum of these cross-correlation functions defined the corresponding time lag $\tau$. In a first modeling step, we examined cross-correlation functions separately for the AL and RE periods. Because both periods yielded comparable results (data not shown), we estimated the final cross-correlation functions over both periods. Examples of cross-correlation functions are provided in Supplementary Figure 1 (available online at http://www.journalofdairyscience.org/). During the AL period, Pearson correlation coefficients for linear regression between the amount of feed ingested per feed intake event and the corresponding $\mathrm{FOX}_{\text {net }}$ decrease or $\mathrm{COX}_{\text {net }}$ increase (difference between consecutive turning points), respectively, were calculated. During the $\mathrm{RE}$ period, changes in $\mathrm{FOX}_{\text {net }}$ or $\mathrm{COX}_{\text {net }}$, respectively, occurring after the last feed intake were exponentially regressed by $\mathrm{y}=\mathrm{y}_{0}+\mathrm{a} \times[1-\exp (-\mathrm{b} \times \mathrm{x})]$ for $\mathrm{FOX}_{\text {net }}$ and $\mathrm{y}=\mathrm{y}_{0}+\mathrm{a} \times \exp (-\mathrm{b} \times \mathrm{x})$ for $\mathrm{COX}_{\text {net }}$, with $\mathrm{x}=1$, $2,3, \ldots$, coding a 6 -min measuring interval (Table 2).

\section{RESULTS}

\section{Associations Between Feed Intake and Periprandial FOX ${ }_{\text {net }}$}

Throughout the AL period, all animals showed negative $\mathrm{FOX}_{\text {net }}$, which is indicative of prevailing net lipogenesis (Figure 1). At the beginning of the RE period, animals remained in a lipogenic state as indicated by the negative $\mathrm{FOX}_{\text {net }}$ scale for $16 \pm 2 \mathrm{~h}$ but reached FOX $_{\text {net }} \geq 0 \mathrm{~g}$ thereafter. The interval between the last feed intake during $\mathrm{RE}$ and the emergence of a balanced FOX $_{\text {net }}$ lasted for $5 \pm 1 \mathrm{~h}$. Throughout the RE period, the increase of $\mathrm{FOX}_{\text {net }}$ followed an exponential relationship in all animals (Table 2), asymptotically approaching a mean maximum $\mathrm{FOX}_{\text {net }}$ rate $\left[\mathrm{FOX}_{\text {net(max }}\right]$ of $\sim 0.1 \mathrm{~g} / \mathrm{min}$. Considering both the AL and RE periods, cross-correlation analysis revealed that each feed intake event strongly paralleled a decrease in FOX $_{\text {net }}$ (Table 3). In this context, each maximum of a feed intake event was followed by a $\mathrm{FOX}_{\text {net }}$ minimum with an offset of $\tau$ ranging between 30 and $42 \mathrm{~min}$ (Table 3; Supplementary Figures S1 and S2, available online at http://www.journalofdairyscience.org/), whereas the extent of prandial + postprandial FOX ${ }_{\text {net }}$ decrease 
Table 2. Exponential regression for net fat oxidation $\left(\mathrm{FOX}_{\text {net }}\right)$ and net carbohydrate oxidation $\left(\mathrm{COX}_{\text {net }}\right)$ rate, respectively, after the last feed intake during the restricted period

\begin{tabular}{lcccc}
\hline Item $^{1}$ & Cow 1 & Cow 2 & Cow 3 & Cow 4 \\
\hline FOX $_{\text {net }}$ & & & & \\
$\mathrm{y}_{0}$ & -7.069 & -8.952 & -12.622 & -7.762 \\
$\mathrm{a}$ & 9.253 & 8.880 & 12.480 & 8.591 \\
$\mathrm{~b}$ & 0.033 & 0.060 & 0.086 & 0.021 \\
$\mathrm{y}_{(\max )}$ & 2.185 & -0.072 & -0.141 & 0.829 \\
$\mathrm{R}^{2}$ & 0.95 & 0.92 & 0.96 & 0.93 \\
$\mathrm{COX}_{\text {net }}$ & & & & \\
$\mathrm{y}_{0}$ & 15.275 & 16.776 & 20.058 & 13.351 \\
$\mathrm{a}$ & 33.635 & 32.072 & 0.0935 & 0.014 \\
$\mathrm{~b}$ & 0.026 & 0.020 & 20.058 & 13.351 \\
$\mathrm{y}_{(\min )}$ & 15.275 & 16.776 & 0.94 & 0.96 \\
$\mathrm{R}^{2}$ & 0.97 & 0.96 & & \\
\hline
\end{tabular}

${ }^{1}$ The general equations were as follows: $\mathrm{y}=\mathrm{y}_{0}+\mathrm{a} \times[1-\exp (-\mathrm{b} \times \mathrm{x})]$ for $\mathrm{FOX}_{\text {net }}$ and $\mathrm{y}=\mathrm{y}_{0}+\mathrm{a} \times \exp (-\mathrm{b}$ $\times \mathrm{x}$ ) for $\mathrm{COX}_{\text {net }}$, where $\mathrm{y}=\mathrm{FOX}_{\text {net }}$ or $\mathrm{COX}_{\text {net }}$, respectively; $\mathrm{y}_{0}, \mathrm{a}$, and $\mathrm{b}$ are coefficients, $\mathrm{R}^{2}$ is the coefficient of determination, $\mathrm{y}_{(\max )}$ or $\mathrm{y}_{(\min )}=$ the asymptotic value, and $\mathrm{x}=$ number of time interval $(6 \mathrm{~min})$. All coefficients were significant with $P<0.0001$.

correlated strongly with the amount of feed ingested during the corresponding feed intake event (Table 4). During between-feed intake intervals, FOX $_{\text {net }}$ reincreased according to the exponential rate determined during the RE period (Table 2). When FOX net $_{\text {reached }}$ a threshold value of -0.7 to $-0.2 \mathrm{~g} / \mathrm{min}$, the next feed intake event started; however, there was no individual animal $\mathrm{FOX}_{\text {net }}$ set-point determining the start of the next feed intake event. Interestingly, when this FOX $_{\text {net }}$ rate was exceeded during feed restriction, plasma NEFA accumulated, although we found no cross-correlation between FOX $_{\text {net }}$ and NEFA.

\section{Associations Between Feed Intake and Periprandial COX $\mathrm{C}_{\text {net }}$}

Each feed intake event was strongly associated with an increase in $\mathrm{COX}_{\text {net }}$ (Figure 1, Table 3), which already started increasing during a feed intake event. The $\mathrm{COX}_{\text {net }}$ peak occurred in all animals with an offset of $\tau$ ranging between 30 and 42 min after each feed intake peak (Table 3, Supplementary Figure S2; http://www. journalofdairyscience.org/). Moreover, the amount of feed ingested was highly correlated with the extent of the prandial + postprandial COX $_{\text {net }}$ increase (Table 4). Between 2 consecutive feed intake events, $\mathrm{COX}_{\text {net }}$ decreased at an exponential rate as determined after the last feed intake in the RE period (Table 2), but $\mathrm{COX}_{\text {net }}$ rate did not decrease below $\sim 6 \mathrm{~g} / \mathrm{min}$ before the next feed intake event began. The asymptotically approaching minimum $\mathrm{COX}_{\text {net }}$ rate $\left[\mathrm{COX}_{\text {net(min) }}\right]$ calculated for the period after the last feed intake during $\mathrm{RE}$ was, in contrast to $\mathrm{FOX}_{\text {net(max) }}$, of the same order of magnitude for all animals. In addition, milking had no effect on FOX $_{\text {net }}$ or $\mathrm{COX}_{\text {net }}$ (data not shown).

\section{Associations Between Periprandial COX net Glucose, and Insulin Concentrations}

Periprandial plasma glucose concentrations ranged between 3.5 and $5.0 \mathrm{mmol} / \mathrm{L}$ during both the AL and the RE periods. As particularly evident during the $\mathrm{AL}$ period, plasma glucose concentration reached a low point after an average of $54 \mathrm{~min}$ after every $\mathrm{COX}_{\text {net }}$ maximum; vice versa, when $\mathrm{COX}_{\text {net }}$ reached a temporal minimum, the subsequent plasma glucose peak was observed with an offset of $54 \mathrm{~min}$ (Table 3 ).

In cows 1,2 , and 3 , plasma insulin concentrations strongly paralleled periprandial $\mathrm{COX}_{\text {net }}$ without any lag $(\tau=0$ min; Table 3$)$. Only cow 4, which also differed in HP and BHBA from the other cows (see below), responded with an insulin surge 216 min after the $\mathrm{COX}_{\text {net }}$ maximum during AL. Comparably, we observed an offset between glucose and insulin in cow $4(\tau=54 \mathrm{~min})$ but a strong inverse relationship without measurable lag $(\tau=0 \mathrm{~min})$ in the other 3 animals (Table 3 ).

\section{Associations Between HP and BHBA}

During the AL period, HP peaked instantaneously in response to each feed intake event but decreased during the fasted state (i.e., during the RE period). In parallel, BHBA increased in response to feed intake and declined at the end of the RE period. As a result, we found a high direct cross-correlation without any delay between HP and plasma BHBA concentration for cows 1, 2, and 3 , whereas cow 4 lagged behind with a 270 -min time offset to the HP peak (Table 3 ).

\section{Associations Between Plasma Metabolites and Hormones}

With the exception of cow 1, the periprandial course of ghrelin was highly cross-correlated with plasma 


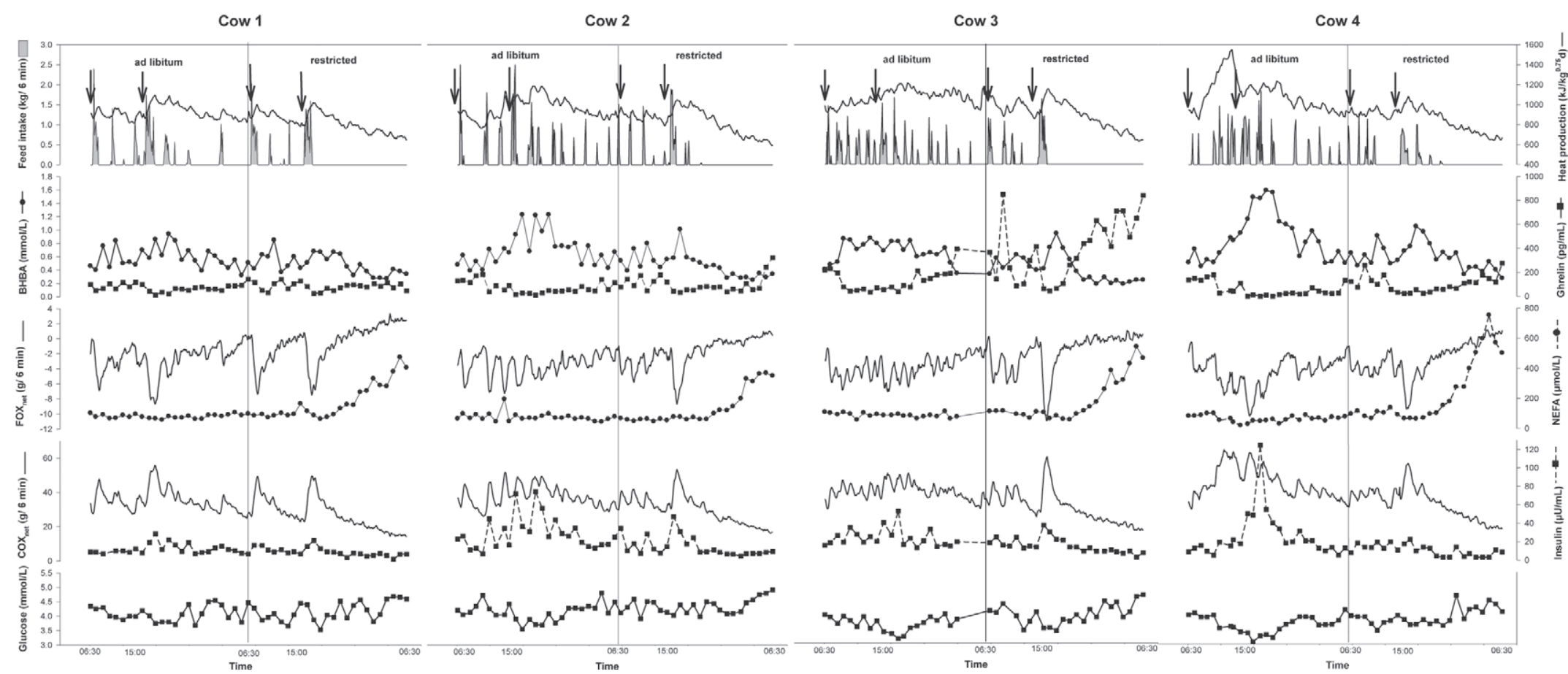

Figure 1. Dynamics of feed intake, heat production, net fat oxidation $\left(\mathrm{FOX}_{\text {net }}\right)$, net carbohydrate oxidation $\left(\mathrm{COX}_{\text {net }}\right)$, plasma glucose, BHBA, NEFA, insulin, and ghrelin concentrations in 4 cows in late lactation during a 48-h stay in the respiration chamber. On the first experimental day, cows were fed ad libitum (AL), and on the second day, they received $50 \%$ of the $\mathrm{AL}$ amount (restricted, RE); vertical lines separate $\mathrm{AL}$ and RE periods. Equally sized meals were offered twice daily each at 0700 and $1500 \mathrm{~h}$ (indicated by arrows) 
Table 3. Time lag $(\tau)$ and corresponding Pearson cross-correlation coefficients $(\mathrm{r})$ between feed intake and respiratory and plasma parameters in 4 lactating Holstein cows ${ }^{1}$

\begin{tabular}{|c|c|c|c|c|c|}
\hline Item $^{2}$ & Parameter & Cow 1 & Cow 2 & Cow 3 & Cow 4 \\
\hline \multirow[t]{2}{*}{$\mathrm{FI} \rightarrow \mathrm{FOX}_{\text {net }}$} & $\tau, \min$ & 42 & 36 & 30 & 42 \\
\hline & $\mathrm{r}$ & -0.58 & -0.53 & -0.60 & -0.53 \\
\hline \multirow{2}{*}{$\mathrm{FI} \rightarrow \mathrm{COX}_{\text {net }}$} & $\tau, \min$ & 42 & 36 & 30 & 36 \\
\hline & $\mathrm{r}$ & 0.55 & 0.47 & 0.51 & 0.47 \\
\hline \multirow[t]{2}{*}{$\mathrm{COX}_{\text {net }} \rightarrow$ Glucose } & $\tau, \min$ & 54 & 54 & 54 & 54 \\
\hline & $\mathrm{r}$ & -0.59 & -0.60 & -0.42 & -0.83 \\
\hline \multirow{2}{*}{$\mathrm{COX}_{\text {net }} \rightarrow$ Insulin } & $\tau, \min$ & 0 & 0 & 0 & 216 \\
\hline & $\mathrm{r}$ & 0.80 & 0.80 & 0.89 & 0.66 \\
\hline \multirow[t]{2}{*}{ BHBA $\rightarrow$ Heat production } & $\tau, \min$ & 0 & 0 & 0 & 240 \\
\hline & $\mathrm{r}$ & 0.73 & 0.81 & 0.81 & 0.81 \\
\hline \multirow[t]{2}{*}{ Insulin $\rightarrow$ Glucose } & $\tau, \min$ & 0 & 0 & 0 & 54 \\
\hline & $\mathrm{r}$ & -0.61 & -0.67 & -0.46 & -0.66 \\
\hline \multirow[t]{2}{*}{ BHBA $\rightarrow$ Ghrelin } & $\tau, \min$ & 0 & 0 & 0 & 162 \\
\hline & $\mathrm{r}$ & -0.48 & -0.49 & -0.75 & -0.54 \\
\hline \multirow[t]{2}{*}{ Ghrelin $\rightarrow$ NEFA } & $\tau, \min$ & - & 54 & 162 & 108 \\
\hline & $\mathrm{r}$ & NS & 0.43 & 0.85 & 0.55 \\
\hline
\end{tabular}

${ }^{1}$ All coefficients are significant at $P<0.05$.

${ }^{2} \mathrm{FI}=$ feed intake amount; $\mathrm{FOX}_{\mathrm{net}}=$ net fat oxidation; $\mathrm{COX}_{\mathrm{net}}=$ net carbohydrate oxidation.

NEFA concentrations (but not with $\mathrm{FOX}_{\text {net }}$ ), as particularly evident in their parallel slopes during the last 14 $\mathrm{h}$ of RE (Table 3). Moreover, periprandial ghrelin and BHBA concentrations were inversely cross-correlated without a time lag in cows 1,2 , and 3 , but with a lag of $162 \mathrm{~min}$ in cow 4 (Table 3 ).

\section{DISCUSSION}

Because of the lack of unanimity as to the appropriate definitions of a "meal" of a cow (Tolkamp et al., 2011), we herein used the term "feed intake event" to define each peak bordered by nonfeeding intervals, as represented in Figure 1. Cases in which cows stopped eating to drink and then immediately resumed eating were recorded as belonging to the same feed intake event.

Furthermore, because indirect calorimetry estimates only the total net loss of substrates (carbohydrates or lipids) and their conversion to $\mathrm{CO}_{2}$ and $\mathrm{H}_{2} \mathrm{O}$ but does not consider any exchange or cycling that the substrate itself or its intermediates undergo along the biochemical pathway to complete oxidation (Ferrannini, 1992), we termed this "disappearance" or "net loss" by oxidation, $\mathrm{COX}_{\text {net }}$ and $\mathrm{FOX}_{\text {net }}$, respectively. Even for those reactions that do involve respiratory gases (e.g., oxidation), indirect calorimetry does not quantify these metabolic transformation, exchange, or cycling processes. In this regard, measurement of $\mathrm{COX}_{n e t}$, which is primarily determined by acetic acid oxidation, is not confounded by acetic acid degraded from long-chain fatty acids. Vice versa, FOX $_{\text {net }}$ is not confounded by acetic acid originating from carbohydrate sources because the indirect calorimetric technique does not "see" intermediates.

The high cross-correlations between each feed intake event with local $\mathrm{FOX}_{\text {net }}$ and $\mathrm{COX}_{\text {net }}$ minima and maxima, respectively, show the biological meaning of each of these peaks, which also led us to refrain from clustering several consecutive feed intake events to socalled feeding bouts, despite this approach being sug-

Table 4. Linear regression between the amount of feed ingested during a feed intake (FI) event and the corresponding net fat oxidation $\left(\mathrm{FOX}_{\text {net }}\right)$ or net carbohydrate oxidation $\left(\mathrm{COX}_{\text {net }}\right)$ alteration, respectively, in 4 lactating Holstein cows $^{1}$

\begin{tabular}{lcccc}
\hline Regression between last FI and & Cow 1 & Cow 2 & Cow 3 & Cow 4 \\
\hline Prandial + postprandial FOX $_{\text {net }}$ & & & & \\
$\mathrm{R}^{2}$ & 0.84 & 0.43 & 0.53 & 0.45 \\
$\mathrm{~b}$ & -0.573 & -0.419 & -0.582 & -0.363 \\
$P$-value & $<0.001$ & 0.021 & 0.002 & 0.012 \\
Prandial + postprandial COX & & & & \\
$\mathrm{R}^{2}$ & 0.95 & 0.40 & 0.71 & 0.30 \\
$\mathrm{~b}$ & 1.983 & 1.412 & 2.274 & 0.845 \\
$P$-value & $<0.001$ & 0.027 & $<0.001$ & 0.053 \\
\hline
\end{tabular}

${ }^{1}$ According to the general equation $\mathrm{y}=\mathrm{a}_{0}+\mathrm{b} \times \mathrm{FI}$, where $\mathrm{y}=\mathrm{FOX}_{\text {net }}$ or $\mathrm{COX}_{\text {net }}$ and $\mathrm{a}_{0}=$ basal $\mathrm{FOX}_{\text {net }}$ or basal $\mathrm{COX}_{\text {net }}$, respectively, the slope of linear regression (b) and the coefficient of determination $\left(\mathrm{R}^{2}\right)$ are shown. 
gested by Tolkamp et al. (2011). Moreover, the pattern of fuel oxidation (minute to minute) is what affects feeding behavior because the amount of oxidation over longer periods (hours or days) is relatively constant and determined by the energy requirements of peripheral organs (Allen et al., 2009), with highest demands in the muscles and liver (Ferrell, 1988). In this regard, it has been shown that lactating dairy cows use about $40 \%$ of the total oxygen supply for hepatic oxidative processes (Reynolds et al., 2003). Because hepatic glucose oxidation is negligible in ruminants, increasing hepatic fatty acid oxidation is thought to depress feed intake (Allen et al., 2009). Our findings support this hypothesis, demonstrating that $\mathrm{FOX}_{\text {net }}$ increases to a certain degree while no feed is ingested between 2 feeding events. Studies in sheep suggest that signals generated by hepatic oxidation of several fuels are transmitted via the vagus nerve to the brain to terminate feed intake (Anil and Forbes, 1980). However, the increase of FOX net $_{\text {, }}$, which we have shown obeys an exponential function (Table 2), ends with the next feed intake event and so it seems that cows in established lactation start to eat to keep the $\mathrm{FOX}_{\text {net }}$ rate from becoming too positive (see below). A defined $\mathrm{FOX}_{\text {net }}$ threshold at which the next feed intake event is initiated, however, could not clearly be detected, but it ranged very narrowly between -0.7 and $-0.2 \mathrm{~g} / \mathrm{min}$. Only when this FOX ${ }_{\text {net }}$ threshold was exceeded did plasma NEFA concentrations start to accumulate, indicating the lack of cross-correlation between periprandial FOX net $_{\text {and }}$ plasma NEFA concentrations. Interestingly, average $\mathrm{FOX}_{\text {net(max) }}$ approached $\sim 0.1 \mathrm{~g} / \mathrm{min}$ in response to feed restriction but differed markedly between animals (see FOX $_{\text {net(max) }}$ in Table 2 ), referring to an individual oxidative capacity and thus metabolic flexibility for adjusting to the lipolytic state. This inter-individual variance, however, was not evident for the coefficients $\mathrm{a}, \mathrm{b}$, and $\mathrm{y}_{0}$ (see Table 2).

During a feed intake event, we found steeply decreasing FOX $_{\text {net }}$. This likely occurs because hepatic oxidation of NEFA is limited during meals by increased insulin secretion and inhibited lipolysis from adipose tissue, and because propionate, which is intensively absorbed during meals, inhibits $\beta$-oxidation. Inhibition of $\beta$-oxidation in the liver and muscle has been shown to provide a signal for increasing (perhaps prolonging?) food intake in rats (Friedman et al., 1999). In line with this, we found a strong inverse correlation between the prandial + postprandial decrease of $\mathrm{FOX}_{\text {net }}$ and the corresponding amount of feed ingested (Table 4). However, we also observed that FOX $_{\text {net }}$ still decreased even though the previous feed intake event had already finished. The latter finding may raise some doubts that pharmaceutical inhibition of $\beta$-oxidation would enable dairy cows to continue with feed intake, as was shown for rodents (Friedman and Tordoff, 1986; Scharrer and Langhans, 1986). Nevertheless, the continuous decrease of FOX ${ }_{\text {net }}$ after the latest feed intake event has finished is likely because of the ongoing absorption of propionate from the rumen, which in turn occurs with delay because of the prior necessity of microbial fermentation.

In the rumen, starch, as the major carbohydrate source, is converted by microbes into VFA, which in turn are oxidized by the metabolism of the cow. Thus, the observation of increased $\mathrm{COX}_{\text {net }}$ in response to each feed intake event is primarily attributed to the oxidation of VFA and also, albeit to a minor extent, to the lactate production from glucose in the small intestine. Propionate is primarily oxidized in the liver during meals, and according to the hepatic oxidation theory (Allen et al., 2009), the energy state of hepatocytes increases, generating a satiety signal to terminate feed intake. Our results obtained on a whole-body level partly reflecting liver metabolism may support this hypothesis because $\mathrm{COX}_{\text {net }}$ begins to increase prandially and continuously increases while the latest feed intake event has already finished. Within the subsequent between-feed intake interval, $\mathrm{COX}_{\text {net }}$ decreased to a different extent, although the $\mathrm{COX}_{\text {net }}$ rate never decreased below $\sim 6 \mathrm{~g} / \mathrm{min}$ before the start of the next feed intake event. It thus appears that a decelerated $\mathrm{COX}_{\text {net }}$ rate initiates feed intake, an assumption that agrees with the study of Del Prete et al. (2004), which showed that prevention of glucose oxidation in rats stimulates feed intake. Similarly, the 24-h $\mathrm{COX}_{\text {net }}$ rate determined in a respiratory chamber was negatively correlated with daily energy intake in humans (Pannacciulli et al., 2007). Taken together, these results imply that in several mammalian species a general mechanism exists in which oxidation of dietary carbohydrates is involved in the control of feed intake, regardless of whether VFA or glucose is used as metabolic substrate.

Dynamics of $\mathrm{COX}_{\text {net }}$ and plasma glucose were offset by $\tau=54 \mathrm{~min}$ in all animals, representing a homeostatic system with mutually coordinated whole-body glucose oxidation and hepatic glucose production. However, because of the relatively long period between 2 consecutive plasma data points $(\sim 60 \mathrm{~min})$, caution must be given in interpreting the absolute $\tau$ lags involving plasma metabolites or hormones, which could actually be shorter.

We have further shown that whole-body net oxidation of carbohydrates decays in an exponential manner later postprandially and in response to fasting. As a key player in the maintenance of glucose homeostasis, plasma insulin levels were, as expected, inversely crosscorrelated with plasma glucose. In addition to this, plasma insulin strongly paralleled periprandial $\mathrm{COX}_{\text {net }}$ without any lag in most cows, reflecting the well-known 
role of insulin in promoting glucose uptake in peripheral organs and increasing oxidation of gluconeogenic precursors such as propionate or lactate.

Furthermore, our results show that diet-induced HP strongly paralleled plasma BHBA concentration during both the AL and RE periods. In nonruminants, BHBA produces only a minor thermic effect (Chioléro et al., 1993) and even inhibits noradrenaline-induced thermogenesis (Cañas et al., 1998), suggesting that in cows the postprandial increase of BHBA concentrations occurs not only as a result of feed intake when produced by rumen epithelial cells but also acts as a counter-regulatory signal to prevent excessive diet-induced thermogenesis.

Whereas BHBA is produced from ruminal butyrate after each feed intake event, ghrelin is released with decreasing rumen fill (Gregorini et al., 2009), which usually occurs before meals (Wertz-Lutz et al., 2006). In line with this, we demonstrated that periprandial BHBA and ghrelin concentrations were inversely crosscorrelated. However, although the orexigenic property of acylated ghrelin in ruminants has recently been questioned (Iqbal et al., 2006), BHBA reduces orexigenic signaling in hypothalamic cells (Laeger et al., 2012) and food intake in small ruminants (Rossi et al., 2000). In the current study, significant cross-correlations between feed intake events and BHBA or ghrelin, respectively, could not be identified, probably because plasma samples were withdrawn at predefined hourly intervals and not in relation to single feed intake events. This likely explains why we found no significant cross-correlations between ghrelin and $\mathrm{FOX}_{\text {net }}$ but did between ghrelin and NEFA. In addition, the courses of plasma ghrelin and NEFA were highly parallel, particularly during the $\mathrm{RE}$ period, but whether both variables increase independently of each other remains to be determined. Moreover, whether ghrelin contributes to the elevation of NEFA as demonstrated when infused in cows (ThidarMyint et al., 2006), or whether acylation of ghrelin is triggered in a lipid-rich environment, such as in response to fasting-induced NEFA release or feeding rumen-protected long-chain fatty acids (Fukumori et al., 2011), is subject to further investigations.

It seems that only 1 of the 4 cows (no. 4) differed in terms of $\tau$ from the other animals shown in Table 3 . The longer lags observed in cow 4 may be due to the fact that, during AL, it had the highest amplitudes in HP, $\mathrm{COX}_{\text {net }}$, and $\mathrm{FOX}_{\text {net }}$, as well as the highest plasma insulin and BHBA concentrations compared with the other animals, suggesting longer-lasting periods to regulate homeostasis. However, despite the higher $\tau$ and $\mathrm{b}$ values (see Tables 3 and 4), metabolically related plasma and respiratory parameters were highly cross-correlated in cow 4, and the cross-correlation coefficients (r) were in the same range as those of the other animals.

\section{CONCLUSIONS}

Each single feed intake event induced a nearly constant time-delayed change in net carbohydrate and net fat oxidation. Because postprandial FOX $_{\text {net }}$ never increased above $-0.2 \mathrm{~g} / \mathrm{min}$ and postprandial $\mathrm{COX}_{\text {net }}$ never decreased below $6 \mathrm{~g} / \mathrm{min}$ before the start of the next feed intake event and because these thresholds ranged only very narrowly, late-lactating cows fed ad libitum seem to initiate feed intake in response to an accelerated $\mathrm{FOX}_{\text {net }}$ rate and a decelerated $\mathrm{COX}_{\text {net }}$ rate, respectively. Because postprandial increases in $\mathrm{COX}_{\text {net }}$ and $\mathrm{FOX}_{\text {net }}$ coincide with times in which cows do not eat, assuming they are satiated, metabolic oxidative processes seem to signal feed intake suppression, which lends support to the hepatic oxidation theory.

\section{ACKNOWLEDGMENTS}

This study was financed by the core budget of the Leibniz Institute for Farm Animal Biology (FBN, Dummerstorf, Germany). We thank Ulrike Wiedemuth (Research Unit Reproduction Biology), Dirk Oswald, Bert Fölsch, Burkhard Hallier, Marlies Althaus, Heike Pröhl, Nicole Lüdke, Claudia Arlt, Astrid Schulz, and Kerstin Pilz (Research Unit Nutritional Physiology "Oskar Kellner" at FBN Dummerstorf). The authors also thank Gerhard Manteuffel (Research Unit Behavioural Physiology at FBN Dummerstorf) for his helpful advice in interpreting feeding behavior.

\section{REFERENCES}

Allen, M. S., B. J. Bradford, and M. Oba. 2009. Board invited review: The hepatic oxidation theory of the control of feed intake and its application to ruminants. J. Anim. Sci. 87:3317-3334.

Anil, M. H., and J. M. Forbes. 1980. Feeding in sheep during intraportal infusions of short-chain fatty acids and the effect of liver denervation. J. Physiol. 298:407-414.

Bines, J. A., I. C. Hart, and S. V. Morant. 1983. Endocrine control of energy metabolism in the cow: Diurnal variations in the concentrations of hormones and metabolites in the blood plasma of beef and dairy cows. Horm. Metab. Res. 15:330-334.

Blümmel, M., K. P. Aiple, H. Steingaß, and K. Becker. 1999. A note on the stoichiometrical relationship of short chain fatty acid production and gas formation in vitro in feedstuffs of widely differing quality. J. Anim. Physiol. Anim. Nutr. (Berl.) 81:157-167.

Bradford, B. J., and M. S. Allen. 2008. Negative energy balance increases periprandial ghrelin and growth hormone concentrations in lactating dairy cows. Domest. Anim. Endocrinol. 34:196-203.

Bradford, B. J., K. J. Harvatine, and M. S. Allen. 2008. Dietary unsaturated fatty acids increase plasma glucagon-like peptide-1 and cholecystokinin and may decrease premeal ghrelin in lactating dairy cows. J. Dairy Sci. 91:1443-1450.

Brouwer, E. 1965. Report of sub-committee on constants and factors. Pages 441-443 in Energy Metabolism of Farm Animals. Academic Press, London, UK.

Cañas, X., J. A. Fernández-López, X. Remesar, and M. Alemany. 1998. 3-Hydroxybutyrate inhibits noradrenaline-induced thermogenesis in lean but not in obese Zucker rats. Int. J. Obes. Relat. Metab. Disord. 22:734-740. 
Carlson, D. B., J. W. McFadden, A. D'Angelo, J. C. Woodworth, and J. K. Drackley. 2007. Dietary L-carnitine affects periparturient nutrient metabolism and lactation in multiparous cows. J. Dairy Sci. 90:3422-3441.

Chioléro, R., P. Mavrocordatos, P. Burnier, M. C. Cayeux, C. Schindler, E. Jéquier, and L. Tappy. 1993. Effects of infused sodium acetate, sodium lactate, and sodium $\beta$-hydroxybutyrate on energy expenditure and substrate oxidation rates in lean humans. Am. J. Clin. Nutr. 58:608-613.

Chwalibog, A., K. Jensen, and G. Thorbek. 1996. Oxidation of nutrients in bull calves treated with $\beta$-adrenergic agonists. Arch. Anim. Nutr. 49:255-261.

Del Prete, E., T. A. Lutz, and E. Scharrer. 2004. Inhibition of glucose oxidation by $\alpha$-cyano-4-hydroxycinnamic acid stimulates feeding in rats. Physiol. Behav. 80:489-498.

Derno, M., H. G. Elsner, E. A. Paetow, H. Scholze, and M. Schweigel. 2009. Technical note: A new facility for continuous respiration measurements in lactating cows. J. Dairy Sci. 92:2804-2808.

Derno, M., W. Jentsch, M. Schweigel, S. Kuhla, C. C. Metges, and H. D. Matthes. 2005. Measurements of heat production for estimation of maintenance energy requirements of Hereford steers. J. Anim. Sci. 83:2590-2597.

Dohme, F., A. Machmüller, F. Sutter, and M. Kreuzer. 2004. Digestive and metabolic utilization of lauric, myristic and stearic acid in cows, and associated effects on milk fat quality. Arch. Anim. Nutr. 58:99-116.

Drackley, J. K. 1999. Biology of dairy cows during the transition period: The final frontier? J. Dairy Sci. 82:2259-2273.

Drackley, J. K., T. H. Klusmeyer, A. M. Trusk, and J. H. Clark. 1992. Infusion of long-chain fatty acids varying in saturation and chain length into the abomasum of lactating dairy cows. J. Dairy Sci. $75: 1517-1526$

Duske, K., H. M. Hammon, A. K. Langhof, O. Bellmann, B. Losand, K. Nürnberg, G. Nürnberg, H. Sauerwein, H. M. Seyfert, and C. C. Metges. 2009. Metabolism and lactation performance in dairy cows fed a diet containing rumen-protected fat during the last twelve weeks of gestation. J. Dairy Sci. 92:1670-1684.

Ferrannini, E. 1992. Equations and assumptions of indirect calorimetry: Some special problems. Pages 1-17 in Energy Metabolism: Tissue Determinants and Cellular Corollaries. J. M. Kinney and H. N. Tucker, ed. Raven Press Ltd., New York, NY.

Ferrell, C. L. 1988. Energy metabolism. Pages 251-268 in The Ruminant Animal, Digestive Physiology and Nutrition. D. C. Church, ed. Prentice Hall, Englewood Cliffs, NJ.

Friedman, M. I., R. B. Harris, H. Ji, I. Ramirez, and M. G. Tordoff. 1999. Fatty acid oxidation affects food intake by altering hepatic energy status. Am. J. Physiol. 276:R1046-R1053.

Friedman, M. I., and M. G. Tordoff. 1986. Fatty acid oxidation and glucose utilization interact to control food intake in rats. Am. J. Physiol. 251:R840-R845.

Fukumori, R., A. Yokotani, T. Sugino, F. Itoh, S. Kushibiki, H. Shingu, N. Moriya, Y. Hasegawa, M. Kojima, K. Kangawa, T. Obitsu, and K. Taniguchi. 2011. Effects of amino acids infused into the vein on ghrelin-induced GH, insulin and glucagon secretion in lactating cows. Anim. Sci. J. 82:267-273.

GfE (German Society of Nutrition Physiology). 2004. Ausschuss für Bedarfsnormen der Gesellschaft für Ernährungsphysiologie, No. 13. Empfehlungen zur Energie- und Nährstoffversorgung der Milchkühe und Aufzuchtrinder (Recommended energy and nutrient supply for dairy cows and growing cattle). DLG-Verlag, Frankfurt am Main, Germany.

Gregorini, P., K. J. Soder, and R. S. Kensinger. 2009. Effects of rumen fill on short-term ingestive behavior and circulating concentrations of ghrelin, insulin, and glucose of dairy cows foraging vegetative micro-swards. J. Dairy Sci. 92:2095-2105.

Iqbal, J., Y. Kurose, B. Canny, and I. J. Clarke. 2006. Effects of central infusion of ghrelin on food intake and plasma levels of growth hormone, luteinizing hormone, prolactin, and cortisol secretion in sheep. Endocrinology 147:510-519.

Laeger, T., R. Pöhland, C. C. Metges, and B. Kuhla. 2012. The ketone body, $\beta$-hydroxybutyric acid influences agouti-related peptide expression via AMP-activated protein kinase in hypothalamic GT1-7 cells. J. Endocrinol. 213:193-203.

Langhans, W., C. Leitner, and M. Arnold. 2011. Dietary fat sensing via fatty acid oxidation in enterocytes: Possible role in the control of eating. Am. J. Physiol. Regul. Integr. Comp. Physiol. 300:R554-R565.

Pannacciulli, N., A. D. Salbe, E. Ortega, C. A. Venti, C. Bogardus, and J. Krakoff. 2007. The 24-h carbohydrate oxidation rate in a human respiratory chamber predicts ad libitum food intake. Am. J. Clin. Nutr. 86:625-632.

Reist, M., D. Erdin, D. vonEuw, K. Tschuemperlin, H. Leuenberger, Y. Chillard, H. M. Hammon, C. Morel, C. Philipona, Y. Zbinden, N. Kuenzi, and J. W. Blum. 2002. Estimation of energy balance individual and herd level using blood and milk traits in high-yielding dairy cows. J. Dairy Sci. 85:3314-3327.

Reynolds, C. K., P. C. Aikman, B. Lupoli, D. J. Humphries, and D. E. Beever. 2003. Splanchnic metabolism of dairy cows during the transition from late gestation through early lactation. J. Dairy Sci. 86:1201-1217.

Rossi, R., S. Dorig, E. Del Prete, and E. Scharrer. 2000. Suppression of feed intake after parenteral administration of D- $\beta$-hydroxybutyrate in pygmy goats. J. Vet. Med. A Physiol. Pathol. Clin. Med. 47:916.

Sartin, J. L., B. K. Whitlock, and J. A. Daniel. 2011. Triennial Growth Symposium: Neural regulation of feed intake: Modification by hormones, fasting, and disease. J. Anim. Sci. 89:1991-2003.

SAS Institute Inc. 2009. SAS/STAT 9.2 User's Guide. 2nd ed. SAS Institute Inc., Cary, NC.

Scharrer, E., and W. Langhans. 1986. Control of food intake by fatty acid oxidation. Am. J. Physiol. 250:R1003-R1006.

Schröder, U. J., and R. Staufenbiel. 2006. Invited review: Methods to determine body fat reserves in the dairy cow with special regard to ultrasonographic measurement of backfat thickness. J. Dairy Sci. 89:1-14.

Simonson, D. C., and R. A. DeFronzo. 1990. Indirect calorimetryMethodological and interpretative problems. Am. J. Physiol. 258:E399-E412.

ThidarMyint, H., H. Yoshida, T. Ito, and H. Kuwayama. 2006. Dosedependent response of plasma ghrelin and growth hormone concentrations to bovine ghrelin in Holstein heifers. J. Endocrinol. 189:655-664.

Tolkamp, B. J., D. J. Allcroft, J. P. Barrio, T. A. Bley, J. A. Howie, T. B. Jacobsen, C. A. Morgan, D. P. Schweitzer, S. Wilkinson, M. P. Yeates, and I. Kyriazakis. 2011. The temporal structure of feeding behaviour. Am. J. Physiol. Regul. Integr. Comp. Physiol. 301:R378-R393.

Vicari, T., J. J. G. C. van den Borne, W. J. J. Gerrits, Y. Zbinden, and J. W. Blum. 2008. Postprandial blood hormone and metabolite concentrations influenced by feeding frequency and feeding level in veal calves. Domest. Anim. Endocrinol. 34:74-88.

Wertz-Lutz, A. E., T. J. Knight, R. H. Pritchard, J. A. Daniel, J. A. Clapper, A. J. Smart, A. Trenkle, and D. C. Beitz. 2006. Circulating ghrelin concentration fluctuate relative to nutritional status and influences feeding behavior. J. Anim. Sci. 84:3285-3300.

Wertz, A. E., T. J. Knight, C. C. Ribeiro-Fiho, D. C. Beitz, and A. Trenkle. 2003. Validation of ghrelin radioimmunoassay (RIA) for use in evaluating physiological factors that influence plasma ghrelin concentrations in beef cattle. J. Anim. Sci. 81 (Suppl. 1):95. (Abstr.)

Wylie, A. R. G., S. Woods, A. F. Carson, and M. McCoy. 2008. Periprandial changes in metabolite and metabolic hormone concentrations in high-genetic-merit dairy heifers and their relationship to energy balance in early lactation. J. Dairy Sci. 91:577-586. 